\title{
Utilization of Open Source Application in Area of Augmented Reality Assembling Processes
}

Ing. Jozef Barna, Ing. Veronika Fecova, prof. Ing. Jozef Novak-Marcincin, PhD., Ing. Jozef Torok

Faculty of Manufacturing Technologies with a seat in Prešov/Department of Production Technologies, Bayerova 1, 08001 Prešov, Slovakia, jozef.barna@tuke.sk

This chapter investigates the establishing process of virtual tool that in its logical core utilizes an approach based on the open source philosophy exploited for the work with the environment of augmented reality and its application in assembling processes. The traditional possibilities of how the engineer can use tools of augmented reality in form of normal commercial devices to collect the information about position of observed object in the working environment concern special devices with general structure formed by elements of motion tracking systems or technology of visual markers. In the beginning, the chapter briefly focuses on general problems in the application processes of virtual components and logical scripts in the area of the augmented reality. In following phase it provides fundamental philosophy and logical steps of new presented application of the augmented reality whereupon some samples can be provided created by means of logical operations and virtual elements from the open source environment. In the final step of this article chapter is clarified application process for creation and development of virtual software and hardware elements that are necessary for work in the augmented reality environment.

Keywords: Augmented Reality, Virtual environment, Open Source

\section{References}

[1] DAKOV, I. S., PETKOVA, A. K.. (2004). Production planning in the Virtual Cellular Manufacturing System. In: Strojírenská technologie, Vol. 9, No. 1, 2004, pp. 9-14, ISSN 1211-4162.

[2] ONG, S. K.; NEE, A. Y. C. (2004). Virtual and Augmented Reality Applications in Manufacturing. SpringerVerlag, ISBN 1-85233-796-6, London.

[3] MARCINCIN, J. N., BRAZDA, P., JANAK, M., KOCISKO, M. (2011). Application of Virtual Reality Technology in Simulation of Automated Workplaces. In: Technicki Vjesnik, Vol. 18, No. 4, 2011, pp. 577-580, ISSN 13303651 .

[4] BARNA, J. (2010). CEURSIS 2010 - the international conference of the carpathian euro-region specialists in industrial systems : 8th edition : proceedings : 12-14 May, 2010, Baia Mare. - Baia Mare : North University, 2010 P. 21-24. - ISBN 978-606-536-094-5

[5] BARNA, J. (2011). Automation in Production Planning and Manufacturing: 12th International Scientific Conference: 03. - 05. May 2011, Žilina - Turčianske Teplice, Slov. - Žilina : Vedecko-technická spoločnost’ pri Žilinskej univerzite, 2011 S. 58-61. - ISBN 978-80-89276-28-8

[6] http://www.vtt.fi/

[7] VALLINO, J; KUTULAKOS, K. N. (2001). Augmenting reality using affine object representations. Fundamentals of Weareable Computers and Augmented Reality. Barfield W. and Caudell T. (Ed.), p. 157-182, Lawrence Erlbaum Assoc. Publ., Mahwah, ISBN 0-8058-2901-6.

[8] http://www.lptcorp.com

[9] ONG, S. K.; PANG,Y.; NEE, A. Y. C. (2007). Augmented Reality Aided Assembly Design and Planning, Annals of the CIRP Vol. 56/1/2007, Innovation in Manufacturing Systems and Technology, Singapore-MIT Alliance, Singapore,Mechanical Engineering Department, National University of Singapore, Singapore,

[10] MARCINČIN, J. N, BARNA, J. (2010). Visualisation Technologies in the Process of Making Composite Structures. In: Trends in the Development of Machinery and Associated Technology, Vol. 14, No. 1, University of Zenica, 2010, pp. 365-369, ISSN 1840-4944.

[11] MARCINČIN, J. N, BARNA, J. (2010). CA Systems Implementation Options in the Design Process of Composite Parts. In: Proceedings of the 10th International Scientific Conference „New Ways in Manufacturing Technologies“, FVT TU, Prešov, 2010, p. 417-422, ISBN 978-80-553-0441-0.

[12] KOČIŠKO, M.; JANÁK, M. (2008) Creation Method of Visual Disassembly Procedure. Journal CA Systems in Production Planning, Vol. 9, No. 1, pp. 37-39, ISSN 1335-3799. 


\section{Acknowledgements}

Ministry of Education, Science, Research and Sport of SR supported this work, contract VEGA No. 1/0036/09, KEGA No. 047-004TUKE-4/2010 and ITMS project 26220220125.

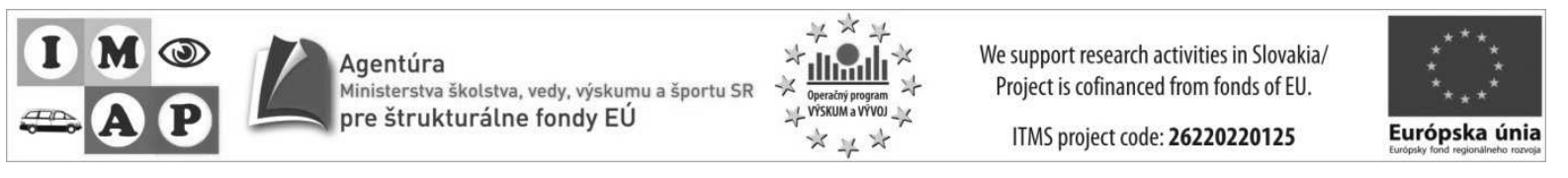

